\title{
Mitochondrial function and nitric oxide metabolism are modified by enalapril treatment in rat kidney
}

\author{
Barbara Piotrkowski, ${ }^{\mathbf{1}}$ Cesar G. Fraga, ${ }^{\mathbf{1 , 2}}$ and Elena M. V. de Cavanagh ${ }^{\mathbf{1}}$ \\ ${ }^{1}$ Physical Chemistry-PRALIB, School of Pharmacy and Biochemistry, University of Buenos Aires, \\ Buenos Aires, Argentina; and ${ }^{2}$ Department of Nutrition, University of California, Davis, California
}

Submitted 27 July 2006; accepted in final form 11 December 2006

\begin{abstract}
Piotrkowski B, Fraga CG, de Cavanagh EMV. Mitochondrial function and nitric oxide metabolism are modified by enalapril treatment in rat kidney. Am J Physiol Regul Integr Comp Physiol 292: R1494-R1501, 2007. First published December 21, 2006; doi:10.1152/ajpregu.00540.2006.-The renal and cardiac benefits of renin-angiotensin system (RAS) inhibition in hypertension exceed those attributable to blood pressure reduction, and seem to involve mitochondrial function changes. To investigate whether mitochondrial changes associated with RAS inhibition are related to changes in nitric oxide (NO) metabolism, four groups of male Wistar rats were treated during 2 wk with a RAS inhibitor, enalapril $\left(10 \mathrm{mg} \cdot \mathrm{kg}^{-1} \cdot \mathrm{day}^{-1}\right.$; Enal), or a NO synthase (NOS) inhibitor, $\mathrm{N}^{\omega}$-nitro-L-arginine methyl ester $(\mathrm{L}-\mathrm{NAME})\left(1 \mathrm{mg} \cdot \mathrm{kg}^{-1} \cdot \mathrm{day}^{-1}\right)$, or both (Enal+L-NAME), or were untreated (control). Blood pressure and body weight were lower in Enal than in control. Electron transfer through complexes I to III and cytochrome oxidase activity were significantly lower, and uncoupling protein-2 content was significantly higher in kidney mitochondria isolated from Enal than in those from control. All of these changes were prevented by L-NAME cotreatment and were accompanied by a higher production/bioavailability of kidney NO. L-NAME abolished mitochondrial NOS activity but failed to inhibit extra-mitochondrial kidney NOS, underscoring the relevance of mitochondrial NO in those effects of enalapril that were suppressed by L-NAME cotreatment. In Enal, kidney mitochondria $\mathrm{H}_{2} \mathrm{O}_{2}$ production rate and $\mathrm{MnSOD}$ activity were significantly lower than in control, and these effects were not prevented by L-NAME cotreatment. These findings may clarify the role of NO in the interactions between RAS and mitochondrial metabolism and can help to unravel the mechanisms involved in renal protection by RAS inhibitors.
\end{abstract}

angiotensin; membrane potential; uncoupling protein; $\mathrm{N}^{\omega}$-nitro-Larginine methyl ester; reactive oxygen species

THE RENIN-ANGIOTENSIN SYSTEM (RAS) plays a critical role as a regulator of systemic blood pressure and electrolyte balance (29, 41). Inhibition of the RAS, either with angiotensin-converting enzyme (ACE) inhibitors or ANG II type 1 (AT1) receptor blockers, lowers blood pressure, and protects the kidney and the heart $(9,26,35,42,52)$ from hypertension-related damage. This protection is not always associated with a reduction in blood pressure (52). Therefore, it is relevant to identify the mechanism(s) underlying the alternative benefits of RAS inhibition.

ACE catalyzes the conversion of ANG I into ANG II, which is the main effector of the RAS. At the cellular level, ANG II binds to the AT1 receptor promoting the generation of both superoxide anion by NADPH-oxidase (72) and nitric oxide (NO) by NO synthase (NOS). Recently, it was shown that ANG II can stimulate the generation of superoxide anion by

Address for reprint requests and other correspondence: E. M. V. de Cavanagh, Physical Chemistry-PRALIB, Univ. of Buenos Aires, Junín 956, 1113-Buenos Aires, Argentina (E-mail: cavanagh@ffyb.uba.ar). uncoupling $\operatorname{NOS}(15,47)$. In addition, ACE degrades bradykinin into inactive metabolites, so ACE inhibition not only prevents ANG II production but also promotes bradykinin accumulation. Bradykinin binds to BK1 and BK2 plasma membrane receptors, thereby activating endothelial NOS (eNOS) and stimulating NO release by endothelial cells (34). Consequently, ACE inhibition may increase eNO production, via a bradykinin-dependent pathway (40).

Mitochondria, the organelles responsible for most of the energy produced in the cell, are also involved in the control of cell signaling and cell death (10, 12, 21). Mitochondria are ubiquitous physiological sources of superoxide anion and NO (7). NO can modulate mitochondrial number (51) and function, and the quantitative relationship between superoxide and NO may be determinant of an appropriate mitochondrial function (8).

Mitochondrial dysfunction has been related to different pathological conditions, such as Alzheimer's and Parkinson's diseases (58), diabetes mellitus (70), obesity and the metabolic syndrome (73), and aging (33). Recent evidence indicates that hypertension may be associated with mitochondrial dysfunction through mechanisms involving increased reactive oxygen species (ROS) production and RAS activation (64). We have shown that long-term RAS inhibition with enalapril, an ACE inhibitor, or losartan, an AT1 receptor blocker, attenuates age-associated structural and functional changes in rat kidney mitochondria (17). Also, losartan was found to attenuate mitochondrial function changes in the kidneys of spontaneously hypertensive rats $(18,19)$. A recent report from Kimura et al. (38) indicates that ANG II stimulates mitochondrial ROS production in vascular smooth muscle cells and in rat aorta in vivo, albeit this increase in ROS production is not involved in the ANG II-mediated elevation of blood pressure. Taken together, these results point to a role for mitochondria in mediating at least part of the beneficial effects displayed by RAS inhibitors.

In the present study, to investigate whether RAS inhibitionassociated changes in NO metabolism might be related to changes in mitochondrial function, we used normotensive rats treated during $2 \mathrm{wk}$ with an ACE inhibitor (enalapril) and/or a NOS inhibitor, $\mathrm{N}^{\omega}$-nitro-L-arginine methyl ester (L-NAME). We found that several of the mitochondrial function changes prompted by enalapril treatment are associated with alterations in NO production or bioavailability.

\section{METHODS}

Chemicals. L-NAME, Percoll, sucrose, BSA, EDTA, malate, glutamate, horseradish peroxidase, scopoletin, antimycin, $\mathrm{H}_{2} \mathrm{O}_{2}$, aproti-

\footnotetext{
The costs of publication of this article were defrayed in part by the payment of page charges. The article must therefore be hereby marked "advertisement" in accordance with 18 U.S.C. Section 1734 solely to indicate this fact.
} 
nin, leupeptin, rhodamine 123 (Rh123), flavin adenine mononucleotide, flavin adenine dinucleotide, Ponceau S, xanthine, xanthine oxidase, tetrahydrobiopterine, and calmodulin were purchased from Sigma-Aldrich (St. Louis, MO). All other reagents were of the highest commercially available purity.

Animals and treatments. Thirty-two male Wistar rats (3 mo old) were randomly divided into four groups of eight animals each. The experimental groups received tap water (control), enalapril (Enal), L-NAME, or enalapril and L-NAME (Enal+L-NAME) during 14 days. Enalapril and L-NAME were administered in the drinking water, so as to provide daily doses of $10 \mathrm{mg}$ enalapril/ $\mathrm{kg}$ body wt, and/or $1 \mathrm{mg}$ L-NAME/kg body wt. The dose of L-NAME was chosen after considering that similar L-NAME doses were shown to have no deleterious effects on kidney structure and function $(45,58)$. The dose of enalapril was chosen on the basis of data from our previous studies (17). The rats had free access to drinking water and food (standard rat chow, Cargill, Buenos Aires, Argentina) and were kept under 12:12-h light-dark cycles. Body weight was determined at the beginning and at the end of the study (day 15). Systolic blood pressure (SBP) was evaluated by tail plethysmography (Polygraph Grass Instrumental, Quincy, MA) on day 15. For kidney isolation, the rats were anesthetized with pentobarbital sodium $(50 \mathrm{mg} / \mathrm{kg}$ body wt $\mathrm{ip}$ ); blood was drawn from the inferior cava vein, and a systemic perfusion was performed with $0.9 \%$ (wt/vol) $\mathrm{NaCl}$ immediately before excision of the kidneys.

Mitochondria isolation. Kidneys were homogenized at $4{ }^{\circ} \mathrm{C}$ in a medium containing $0.23 \mathrm{M}$ mannitol, $0.07 \mathrm{M}$ sucrose, $1 \mathrm{mM}$ EDTA, and $10 \mathrm{mM}$ Tris $\cdot \mathrm{HCl}(\mathrm{pH} \mathrm{7.4)}$, and centrifuged at $600 \mathrm{~g}$ for $10 \mathrm{~min}$, to eliminate nuclei and cellular debris. The supernatant was further centrifuged at $9,000 \mathrm{~g}$ for $10 \mathrm{~min}$. The ensuing pellet was washed once, then it was resuspended in the same medium used to homogenize the tissue (2) and centrifuged at 9,000 $g$ for $10 \mathrm{~min}$. The pellet obtained-referred to as the "mitochondrial fraction"-consists of intact coupled mitochondria able to carry out oxidative phosphorylation (65). The supernatant was further centrifuged at $100,000 \mathrm{~g}$ for 60 min to obtain the "membrane fraction" (25).

To evaluate the activity of mitochondrial NOS (mtNOS), the mitochondrial fraction was suspended in $30 \%$ ( $\mathrm{vol} / \mathrm{vol}$ ) Percoll in, $0.25 \mathrm{M}$ sucrose, $1 \mathrm{mM}$ EDTA, $0.1 \%$ (wt/vol) BSA in $10 \mathrm{mM}$ Tris $\cdot \mathrm{HCl}(\mathrm{pH} 7.4)$, and centrifuged at $95,000 \mathrm{~g}$ for $30 \mathrm{~min}$. Purified mitochondria were washed twice with $150 \mathrm{mM} \mathrm{KCl}$, followed by two washes with $0.23 \mathrm{M}$ mannitol, $0.07 \mathrm{M}$ sucrose, $1 \mathrm{mM}$ EDTA, and 10 $\mathrm{mM}$ Tris $\cdot \mathrm{HCl}(\mathrm{pH}$ 7.4) (17). The purity of the mitochondrial preparation was established by the negligible content of potential contaminants, as evaluated by determining the activities of marker enzymes for microsomes, plasma membrane, lysosomes, and peroxisomes (glucose-6-phosphatase, $0.13 \%$; 5'-nucleotidase, $0.10 \%$; acid phosphatase $2.9 \%$; and catalase, $0.30 \%$, respectively). Protein content was assayed according to Lowry et. al. (44) using BSA as a standard.

NO metabolites. NO metabolites content $\left(\mathrm{NO}_{x}\right)$ was determined by use of the Griess colorimetric reaction, after enzymatic reduction of nitrates to nitrites. Aliquots containing $2 \mathrm{mg}$ of membrane fraction protein were filtered through $30 \mathrm{kDa}$ cut-off membranes (UltraFuge Ultrafiltration Centrifuge Filters, Micron Separations, Westboro, MA) to remove proteins that interfere with the Griess reagent. The filtrates were incubated at room temperature in a medium containing $50 \mu \mathrm{M}$ NADPH, $25 \mathrm{mM}$ glucose-6-phosphate, 8,000 U/L glucose-6-phosphate dehydrogenase, 4,000 U/L nitrate reductase and sodium phosphate $0.7 \mathrm{M}$ ( $\mathrm{pH} 7.4$ ). After $2 \mathrm{~h}, 1 \%$ (wt/vol) sulphanilamide and $1 \%$ (wt/vol) naphthylenediamine were added, and the mixtures were incubated for $10 \mathrm{~min}$. The absorbance of the samples was determined at $540 \mathrm{~nm}$, and sodium nitrate was used as a standard (67).

Mitochondrial enzyme activities. Mitochondrial fractions were used to determine the activities of NADH/cytochrome $c$ oxidoreductase, cytochrome oxidase, and manganese superoxide dismutase (Mn$\mathrm{SOD})$. NADH/cytochrome $c$ oxidoreductase activity was determined by following the reduction of $25 \mu \mathrm{M}$ cytochrome $c$ at $550 \mathrm{~nm}$ in the presence of $0.2 \mathrm{mM} \mathrm{NADH}$ and $0.5 \mathrm{mM} \mathrm{KCN}$, in $100 \mathrm{mM}$ potassium phosphate $(\mathrm{pH}$ 7.2) (32). Cytochrome oxidase activity was measured by following the oxidation of $50 \mu \mathrm{M}$ cytochrome $c$ at $550 \mathrm{~nm}$ in 50 $\mathrm{mM}$ potassium phosphate ( $\mathrm{pH}$ 7.0) (13). Mn-SOD activity was determined by following the inhibition of cytochrome $c$ reduction by superoxide anion at $550 \mathrm{~nm}$, in the presence of $2 \mathrm{mM} \mathrm{NaCN}, 50 \mathrm{mM}$ potassium phosphate, and $10 \mathrm{mM}$ EDTA (pH 7.8) (24). One unit of SOD was defined as the amount of enzyme necessary to cause a $50 \%$ inhibition of the reduction of cytochrome $c$.

Mitochondrial membrane potential. Mitochondrial membrane potential (MMP) was evaluated by determining the accumulation of Rh123 in isolated mitochondria. Rh123 accumulation is driven by MMP and can thus be taken as a MMP index (MMPI) (56). The method used here takes advantage of the red shift in Rh123 absorption and emission fluorescence spectra that occurs when the dye accumulates in mitochondria. The maximun difference in the excitation spectra between coupled and uncoupled mitochondria occurs at 497 and $520 \mathrm{~nm}$. The above-mentioned wavelength shift results in a much greater change in the magnitude of the 520/497 excitation fluorescence ratio than the change in the intensity measured at each wavelength. The reaction took place in a medium containing $150 \mathrm{mM}$ sucrose, $5 \mathrm{mM} \mathrm{MgCl}_{2}, 5 \mathrm{mM}$ potassium phosphate, $20 \mathrm{mM}$ K-HEPES $(\mathrm{pH} 7.4)$, in the presence of $0.2 \mathrm{mg}$ mitochondrial protein, $0.24 \mu \mathrm{M}$ Rh123, $10 \mathrm{mM}$ glutamate, and $5 \mathrm{mM}$ malate at $28^{\circ} \mathrm{C}$. To calibrate the fluorescence ratio for estimation of the MMP, a calibration curve was constructed by plotting 520/490 excitation fluorescence ratios (obtained in the presence of mitochondria and 2,4-dinitrophenol [0, 1, 2, $4,8$, and $16 \mu \mathrm{M}]$ to attain discrete levels of MMP), and the corresponding MMPI values obtained by using the Nernst equation: MMPI = $59 \log ([\mathrm{Rh} 123] \mathrm{in} /[\mathrm{Rh} 123]$ out $)$, where $[\mathrm{Rh} 123]_{\text {in }}$ and [Rh123] $]_{\text {out }}$ were calculated as described elsewhere (56). Rh123 binds to mitochondria causing deviations of MMP-dependent accumulation of Rh123 from that predicted by the Nernst equation. To correct these deviations, binding partition coefficients were obtained by incubating mitochondria in media containing $0.5 \mathrm{mM} \mathrm{KCl}, 20 \mathrm{mM}$ valinomycin, $1 \mu \mathrm{g} / \mathrm{ml}$ rotenone, and varying initial Rh123 concentrations, as described (56).

Mitochondrial hydrogen peroxide production. $\mathrm{H}_{2} \mathrm{O}_{2}$ production was determined in the mitochondrial fraction by following the decrease of scopoletin fluorescence (excitation, $350 \mathrm{~nm}$; emission 460 $\mathrm{nm})$ (37). The reaction was performed in a $3 \mathrm{ml}$-fluorescence cuvette in a medium containing $20 \mathrm{mM}$ Tris $\cdot \mathrm{HCl}$ ( $\mathrm{pH} 7.4), 0.23 \mathrm{M}$ mannitol, $0.07 \mathrm{M}$ sucrose, $0.8 \mu \mathrm{M}$ horseradish peroxidase, $1 \mu \mathrm{M}$ scopoletin, 0.3 $\mu \mathrm{M}$ SOD, $6 \mathrm{mM}$ malate, $6 \mathrm{mM}$ glutamate, $3 \mu \mathrm{M}$ antimycin, $30 \mu \mathrm{M}$ sodium azide, and $0.1 \mathrm{mg}$ mitochondrial protein $/ \mathrm{ml} . \mathrm{H}_{2} \mathrm{O}_{2}(0.05-0.35$ $\mu \mathrm{M})$ was used as a standard.

Mitochondrial NOS activity. The activity of mitochondrial NOS (mtNOS) was evaluated in purified mitochondria by determining the conversion of $\left[{ }^{14} \mathrm{C}\right]$ arginine to $\left[{ }^{14} \mathrm{C}\right]$ citrulline, in a solution containing $50 \mathrm{mM}$ potassium phosphate $(\mathrm{pH} 5.8), 1 \mu \mathrm{M}$ flavin adenine dinucleotide, $1 \mu \mathrm{M}$ flavin adenine mononucleotide, $10 \mu \mathrm{M}$ tetrahydrobiopterine, $0.1 \mu \mathrm{M}$ calmodulin, $300 \mu \mathrm{M} \mathrm{CaCl}_{2}, 100 \mu \mathrm{M}$ NADPH, $60 \mathrm{mM}$ valine, $50 \mu \mathrm{M}$ arginine, $0.025 \mu \mathrm{Ci}\left[{ }^{14} \mathrm{C}\right]$ arginine, and $0.15 \mathrm{mg}$ of mitochondrial protein. The assay mixture was incubated at $37^{\circ} \mathrm{C}$ for 5 min and the reaction stopped by addition of 3 vol of a solution containing $20 \mathrm{mM}$ HEPES (pH 5.5), $2 \mathrm{mM}$ EDTA, and 6 vol of a 50\% (wt/vol) Dowex exchange resin (Bio-Rad, Hercules, CA) solution. The samples were centrifuged at $14,000 \mathrm{~g}$ during $30 \mathrm{~min}$, and an aliquot of the supernatant was used for scintillation counting (39).

Western blot analysis. Uncoupling protein 2 (UCP-2) and eNOS protein contents were determined in the mitochondrial and membrane fractions, respectively. Proteins were separated on SDS- $12.5 \%$ polyacrylamide gels and then transferred to polyvinylidine difluoride membranes, as previously described (17). Membranes were incubated overnight at $4^{\circ} \mathrm{C}$ with either polyclonal UCP-2 (1:100) (Santa Cruz Biotechnology, Santa Cruz, CA), or monoclonal eNOS $(1: 1,500)$ antibodies (Biosystems, Buenos Aires, Argentina) diluted in 2\% 
(wt/vol) low-fat milk. Peroxidase-conjugated secondary antibodies were incubated for $90 \mathrm{~min}$ at room temperature. To reveal bound secondary antibodies, both diaminobenzidine tablets (Sigma, St. Louis, MO) and an enhanced chemiluminiscence kit (Santa Cruz Biotechnology) were used. Western blots were photographed using a digital camera and analyzed with Scion Image software (Scion, Frederick, MD). To normalize samples for protein loading, membranes were stained with $0.5 \%$ (wt/vol) Ponceau $\mathrm{S}$ in $1 \%$ (vol $/ \mathrm{vol})$ acetic acid.

Statistical analysis. Values in the text, Table 1, and figures are expressed as means \pm SE. Statistical analyses were performed by one-way ANOVA and $F$ test (Statview 5.0, SAS Institute, Cary, NC) to establish the significance of between-group differences. $P$ values $<$ 0.05 were considered significant.

\section{RESULTS}

Body weight, kidney weight, and systolic blood pressure. Table 1 shows body weight, kidney weight, and SBP data in rats treated during 14 days with enalapril, L-NAME, or enalapril and L-NAME. At the beginning of the study, body weight showed no differences among groups. At the end of the experimental period, body weight in the Enal group was $14 \%$ lower than in the control group $(P=0.01)$. In the L-NAME group, body weight was higher than in the other groups studied. However, in the Enal+L-NAME group, body weight was similar to that in the control group, suggesting a potential counterbalance between the effects of enalapril and L-NAME. In the L-NAME group, two-kidney weight was significantly higher than in the Enal and Enal+L-NAME groups (Table 1). However, when two-kidney weight was expressed relative to body weight, values were similar in all groups studied. At the end of the study period, SBP in the Enal group was 15 and 22\% lower than in the control $(P<0.02)$ and L-NAME $(P<0.002)$ groups, respectively. In the Enal ${ }_{L}-N A M E$ group, SBP was similar to that found in the control group $(P<0.05)$ (Table 1$)$. Notwithstanding the blood pressure-lowering effects of enalapril, in the Enal group, SBP still remained within the normal physiological range $(4,71)$.

Effects of enalapril and L-NAME on nitric oxide metabolites and eNOS protein contents. Nitrates and nitrites are stable end-products of NO metabolism; therefore, the sum of their contents $\left(\mathrm{NO}_{x}\right)$ is used as an index of tissue $\mathrm{NO}$ production (67). In the Enal and Enal+L-NAME groups, kidney $\mathrm{NO}_{x}$ $\left(10.5 \pm 3.3\right.$ and $10.9 \pm 1.7 \mu \mathrm{g} \mathrm{NO}_{3}{ }^{-} / \mathrm{mg}$ protein, respectively) were significantly higher than in the L-NAME $(4.9 \pm 0.4 \mu \mathrm{g}$ $\mathrm{NO}_{3}{ }^{-} / \mathrm{mg}$ protein) and control groups $\left(4.6 \pm 1.1 \mu \mathrm{g} \mathrm{NO}_{3}{ }^{-} / \mathrm{mg}\right.$ protein) (Fig. 1A). In the Enal group, kidney eNOS protein

Table 1. Body weight, kidney weight, and systolic blood pressure in rats treated with enalapril, L-NAME, or enalapril plus $L-N A M E$, for 14 days

\begin{tabular}{lcccc}
\hline \hline & & & & \\
& Control & Enal & L-NAME & $\begin{array}{c}\text { Enal }+ \\
\text { L-NAME }\end{array}$ \\
\hline Initial body weight, g & $186.7 \pm 8.6$ & $182.6 \pm 6.7$ & $180.7 \pm 4.8$ & $185.7 \pm 8.4$ \\
Final body weight, g & $213.4 \pm 5.1$ & $176.4 \pm 7.7 *$ & $238.2 \pm 7.8 *$ & $193.1 \pm 7.9$ \\
SBP, mm Hg & $113.0 \pm 1.4$ & $96.5 \pm 5.3 * \dagger$ & $121.9 \pm 6.8$ & $110.7 \pm 5.3$ \\
Kidney weight, g & $1.65 \pm 0.11$ & $1.55 \pm 0.06 \dagger$ & $1.91 \pm 0.11$ & $1.42 \pm 0.11 \dagger$ \\
$\begin{array}{l}\text { Kidney weight/body } \\
\text { weight, \% }\end{array}$ & $0.82 \pm 0.06$ & $0.89 \pm 0.04$ & $0.79 \pm 0.03$ & $0.80 \pm 0.02$
\end{tabular}

Values are expressed as means $\pm \mathrm{SE} . * P<0.05$ vs. control; $\uparrow P<0.05$ vs. L-NAME. SBP, systolic blood pressure. content was three to four times higher than in the other groups studied (Fig. 1B).

Effects of enalapril and $L-N A M E$ on mitochondrial function parameters. NADH/cytochrome $c$ oxidoreductase activity was used to examine the capacity for electron transfer through mitochondrial complexes I to III (32). In the control group, NADH/cytochrome $c$ oxidoreductase activity $(30 \pm 9 \mathrm{nmol}$ $\mathrm{NADH} \cdot \mathrm{min}^{-1} \cdot \mathrm{mg}$ protein $\left.{ }^{-1}\right)$ was significantly higher compared with the other groups studied (Fig. 2A). In the Enal group $\mathrm{NADH} /$ cytochrome $c$ oxidoreductase activity was significantly lower than in the Enal + L-NAME group $(2.7 \pm 0.3$ vs. $15.6 \pm$ $3.0 \mathrm{nmol} \mathrm{NADH} \cdot \mathrm{min}^{-1} \cdot \mathrm{mg}$ protein $\left.{ }^{-1}\right)$. Cytochrome $c$ oxidase, the final electron acceptor in the respiratory chain, was determined as another index of mitochondrial respiratory chain capacity. Cytochrome $c$ oxidase activity in the Enal group $\left(5.1 \pm 1.1 \mathrm{nmol}\right.$ cytochrome $\left.c \cdot \mathrm{min}^{-1} \cdot \mathrm{mg} \mathrm{protein}^{-1}\right)$ was significantly lower than in the control (13 \pm 1 nmol cytochrome $c \cdot \min ^{-1} \cdot \mathrm{mg}$ protein $\left.{ }^{-1}\right)$, Enal+L-NAME $(8.9 \pm 0.9$ nmol cytochrome $c / \mathrm{min}^{-1} \cdot \mathrm{mg}$ protein $\left.^{-1}\right)$, and L-NAME $\left(9.8 \pm 1.4 \mathrm{nmol}\right.$ cytochrome $c / \mathrm{min}^{-1} \cdot \mathrm{mg}$ protein $\left.{ }^{-1}\right)$ groups (Fig. $2 B$ ). In the Enal+L-NAME group, cytochrome $c$ oxidase activity was significantly lower than in the control group. $\mathrm{NADH} /$ cytochrome $c$ oxidoreductase and cytochrome $c$ oxidase activities showed a positive correlation $(r=0.42 ; P<$ $0.03)$.

MMP is an indicator of the energy state of the mitochondria (46) that elevated as MMPI was similar among the groups studied (Fig. 3A). In the control group, mitochondrial $\mathrm{H}_{2} \mathrm{O}_{2}$ production $\left(0.93 \pm 0.22 \mathrm{nmol} \mathrm{H}_{2} \mathrm{O}_{2} \cdot \mathrm{min}^{-1} \cdot \mathrm{mg}\right.$ protein $\left.^{-1}\right)$ was higher than in the Enal $(0.47 \pm 0.08 \mathrm{nmol}$ $\mathrm{H}_{2} \mathrm{O}_{2} \cdot \mathrm{min}^{-1} \cdot \mathrm{mg}$ protein $\left.^{-1}\right)$, L-NAME $(0.34 \pm 0.04 \mathrm{nmol}$

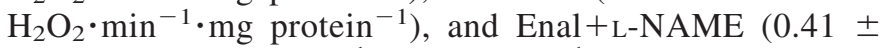
$0.08 \mathrm{nmol} \mathrm{H}_{2} \mathrm{O}_{2} \cdot \mathrm{min}^{-1} \cdot \mathrm{mg}$ protein ${ }^{-1}$ ) groups (Fig. $3 B$ ). $\mathrm{Mn}-\mathrm{SOD}$ is the antioxidant enzyme responsible for the dismutation of superoxide anion, yielding $\mathrm{H}_{2} \mathrm{O}_{2}$. Mn-SOD activity in the Enal (63 $\pm 9 \mathrm{mU} / \mathrm{mg}$ protein) and Enal $+_{\mathrm{L}-\mathrm{NAME}}$ (72 $\pm 7 \mathrm{mU} / \mathrm{mg}$ protein) groups was significantly lower than in the control (129 $\pm 23 \mathrm{mU} / \mathrm{mg}$ protein) and L-NAME (132 \pm 21 $\mathrm{mU} / \mathrm{mg}$ protein) groups (Fig. $3 C$ ). In the Enal group, mtNOS activity was significantly higher than in the control group $\left(1.47 \pm 0.27\right.$ and $0.69 \pm 0.25 \mathrm{nmol}{ }^{14} \mathrm{C}$-citrulline $\cdot \min ^{-1} \cdot \mathrm{mg}$ protein $^{-1}$, respectively), whereas enzyme activity was undetectable in the L-NAME and Enal +L-NAME groups (Fig. 3D). UCP-2 is a widely expressed mitochondrial protein that dissipates the proton electrochemical gradient, thereby uncoupling electron transport and ATP synthesis and decreasing oxidant generation (53). UCP-2 protein content was higher in kidney mitochondria from the Enal group (122.6 \pm 4.6 AU) relative to the control $(101.2 \pm 2.1 \mathrm{AU})$, Enal ${ }_{\mathrm{L}-\mathrm{NAME}}(85.5 \pm 0.5$ AU), and L-NAME (88.8 \pm 3.7 AU) groups (Fig. 3E).

\section{DISCUSSION}

This study shows that short-term RAS inhibition with enalapril modulates NO production, and this modulation is associated with changes in kidney mitochondrial function.

Enalapril treatment lowered SBP relative to control rats, and L-NAME, a competitive NOS inhibitor, prevented the reduction. These results confirm previous observations showing a null effect of the combined administration of enalapril and L-NAME on $\operatorname{SBP}(20,54)$, and reinforce the participation of 
A

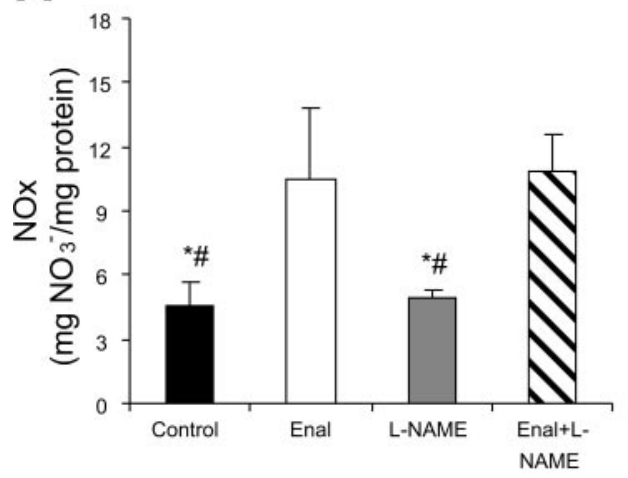

B

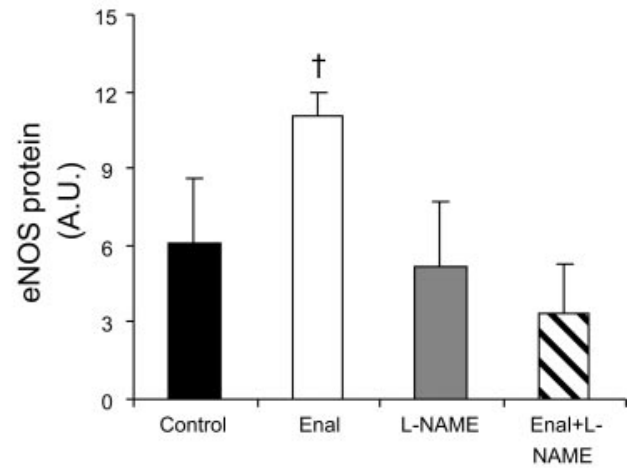

Fig. 1. Kidney nitric oxide (NO) metabolites content $\left(\mathrm{NO}_{x}\right)(A)$ endothelial NO synthase (eNOS) protein contents $(B)$, and a representative SDS-PAGE $(C)$, in rats treated with enalapril (Enal), $N^{\psi}$-nitro-L-arginine methylester (L-NAME), or Enal+L-NAME for 14 days, and controls. Values are expressed as means $\pm \mathrm{SE} ; * P<0.05$ vs. control; $\# P<0.05$ vs. L-NAME; $\dagger P<0.05$ vs. control, L-NAME, and Enal+L-NAME.

C

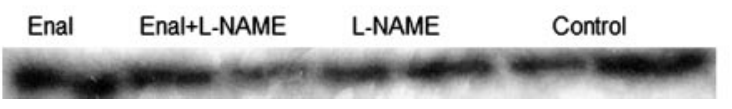

NO in the blood pressure-lowering effect of enalapril. In agreement with other reports $(31,62)$, the administration of enalapril resulted in weight loss and that of L-NAME led to weight gain. These changes were not observed when enalapril and L-NAME were administered together. The inverse relation between NO production and body weight is supported by previous observations showing that in eNOS knockout mice body weight increases. This finding was accompanied with the reductions of mitochondrial biogenesis and energy expenditure $(5,51)$. The experimental design used here, addressing the effects of ACE inhibition on mitochondrial function in the kidney, does not allow us to draw conclusions on the regulation of body weight by enalapril. Rather, it seems reasonable to believe that the effect of enalapril on animal weight is related to the effects of ACE inhibition on adipose tissue RAS and lipid metabolism. In fact, a link between the RAS and lipid metabolism was suggested by studies showing that ANG II can increase both adipose tissue lipid storage and the activity of two key lipogenic enzymes (fatty acid synthase and glycerol-3-phosphate dehydrogenase) and that these effects are blocked by RAS inhibitors $(36,60)$. This evidence suggests that adipose tissue RAS may play a role in body fat accumulation.

Enalapril treatment was associated with a higher production or bioavalability of NO. Accordingly, kidney $\mathrm{NO}_{x}$ was higher in both groups of rats treated with enalapril (Enal and Enal

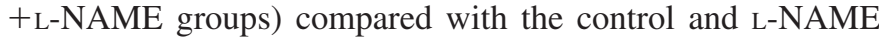
groups. These results are in agreement with previous studies indicating an increase in plasma $\mathrm{NO}_{x}$ in enalapril-treated rats $(16,20,74)$. In the Enal group, the increase in kidney $\mathrm{NO}_{x}$ was accompanied by an increase in kidney eNOS protein content, suggesting that enalapril treatment increased NO production by stimulating eNOS protein expression. In contrast, in the Enal+L-NAME group kidney eNOS protein level was lower and $\mathrm{NO}_{x}$ was higher than in the Enal group. The seemingly paradoxical effect of L-NAME, being unable to block the ability of enalapril to increase kidney $\mathrm{NO}_{x}$ content but being effective in preventing the enhancement of eNOS expression, may be explained considering that 1 ) inducible NOS (iNOS) is a relevant source of $\mathrm{NO}$ in the kidney compared with eNOS and neuronal NOS (nNOS; 1, 27, 66); and 2) L-NAME is 10to 30 -fold selective for inhibiting n-NOS and eNOS relative to iNOS (6). This suggests that kidney iNOS is the isoform

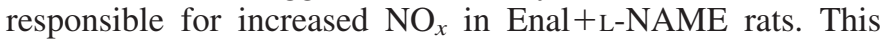
interpretation is also supported by evidence showing that both renal iNOS expression and NO production are negatively modulated by TGF- $\beta$ in vivo (68), and enalapril downregulates TGF- $\beta$ levels in the kidney $(52,61)$.

Interestingly, mtNOS activity was increased in the Enal group compared with control, L-NAME, and Enal+L-NAME groups, pointing to mtNOS as a relevant contributor to enalapril-mediated NO production. Regarding the contrasting effect of L-NAME on renal $\mathrm{NO}_{x}$ and mtNOS activity, it can be proposed that, as indicated above, the extent of inhibition depends on the selectivity of L-NAME for the different NOS isoforms. Even when there is no data on the L-NAME selec-
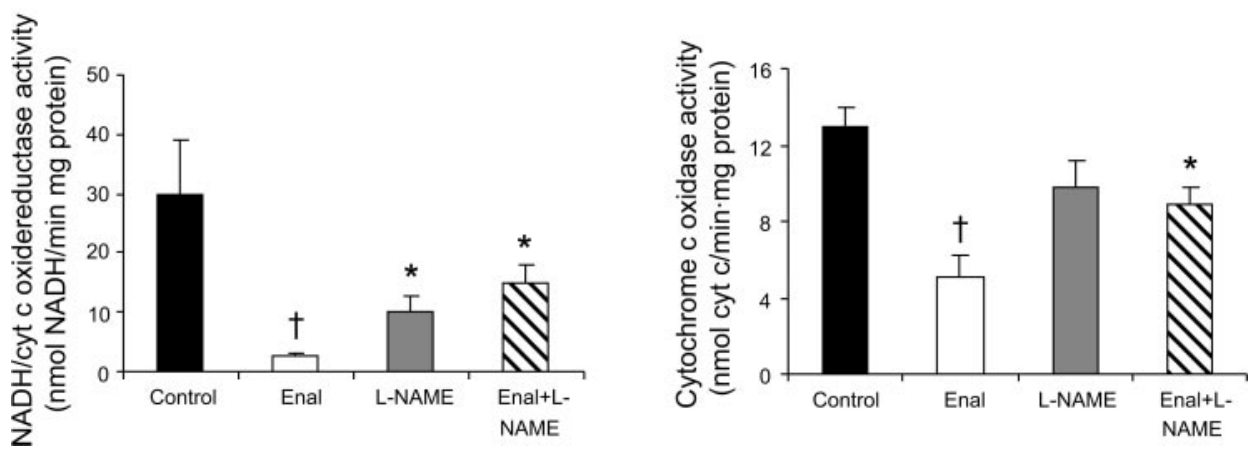

Fig. 2. Mitochondrial respiratory chain enzymes activities in rats treated with Enal, L-NAME, or Enal+L-NAME for 14 days and controls. Values are expressed as means \pm SE. $* P<0.05$ vs. control; $\dagger P<0.05$ vs. control, L-NAME and Enal+L-NAME. 

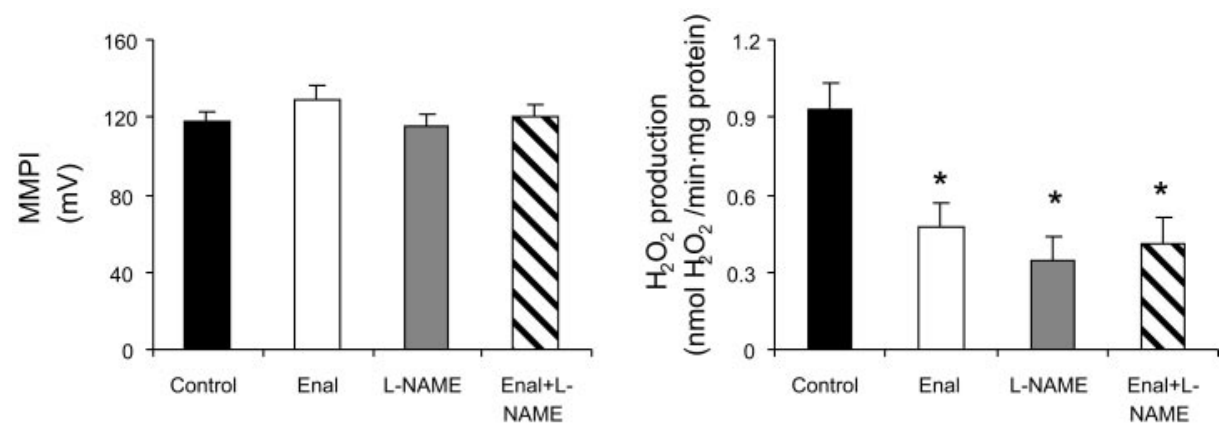

Fig. 3. Mitochondrial function parameters and enzymes activities in rats treated with Enal, L-NAME, or Enal+L-NAME for 14 days, and controls. Values are expressed as means \pm SE. $* P<0.05$ vs. control; \#P<0.05 vs. L-NAME; $\dagger P<0.05$ vs. control, L-NAME and Enal $+_{\mathrm{L}-}$ NAME. Mitochondrial NOS (mtNOS) activity in L-NAME and Enal+L-NAME groups was below the detection limit. MMPI, mitochondrial membrane potential index; UCP-2, uncoupling protein 2.
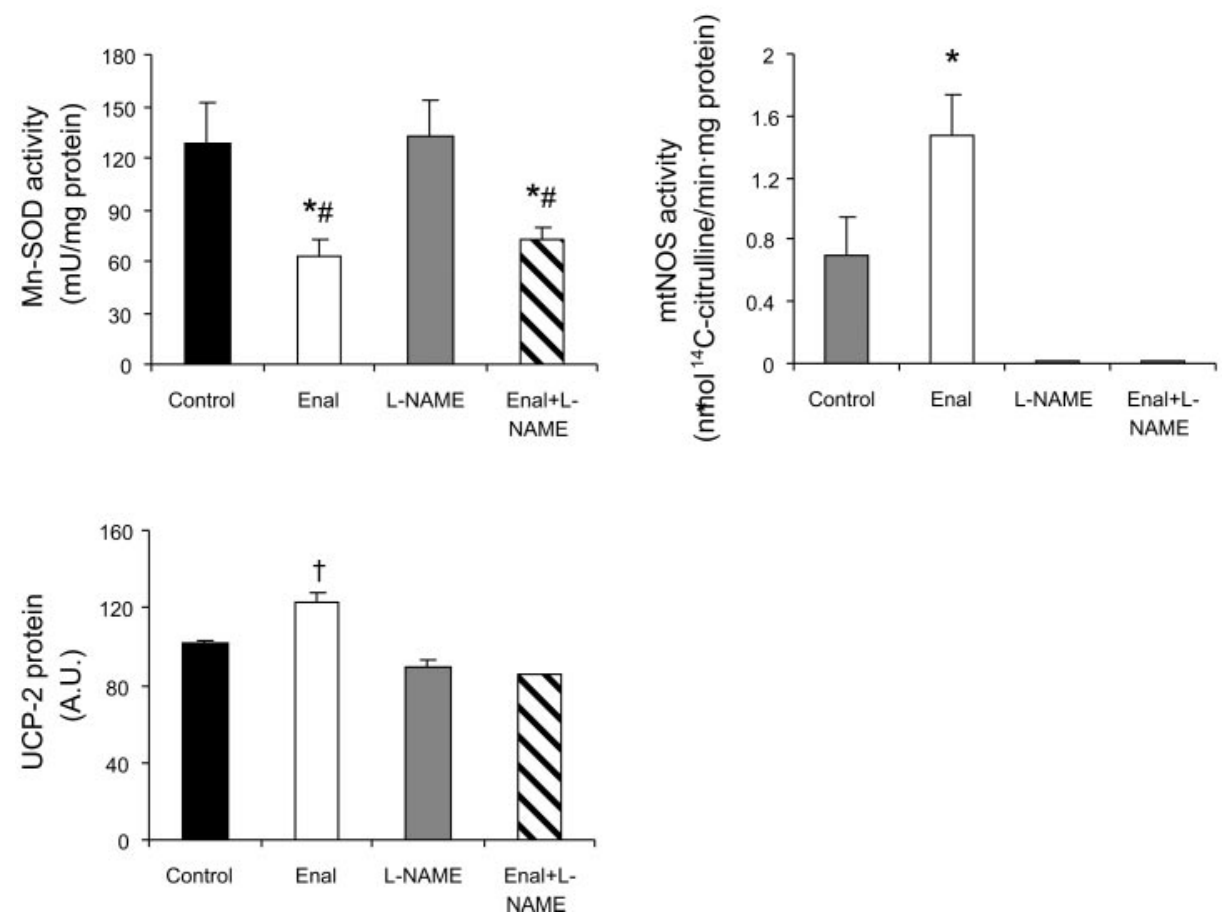

tivity for mtNOS, being that mtNOS is a strong candidate for a subtype of nNOS $(11,30)$, it is expected to be highly susceptible to inhibition by L-NAME. In summary, enalapril upregulated renal eNOS, iNOS, and mtNOS, and cotreatment with L-NAME prevented eNOS and mtNOS upregulation. This suggests that among the mitochondrial effects prompted by enalapril, those that were prevented by cotreatment with LNAME may be attributed to either eNOS or mtNOS, or both.

A wide body of evidence shows that, not only enalapril, but ACE inhibitors in general, as well as AT1 receptor blockers, increase endothelial NO availability via one or more of the following events: 1) attenuation of ANG II-dependent inhibition of eNOS; 2) bradykinin-mediated induction eNOS; and 3) increase in NO steady-state level as a consequence of the attenuation of superoxide production. In addition, NO was found to negatively modulate the RAS through both inhibition of ACE activity and downregulation of AT1 receptors (23). These mechanisms point to a mutual regulation of the RAS and NO-generating enzymes, including mtNOS $(40,63)$. The relationships between NO and the RAS are further complicated by ANG II being able to stimulate NO generation, as it was reported in endothelial cells, as well as in the kidney (23). The ANG II-mediated release of NO from the endothelium was proposed to act as a modulator of the vasoconstrictor action of ANG II on smooth muscle cells. It was also suggested that ANG II may lead to contrasting effects, depending on the cell type with which it interacts. Regarding the effects of ANG II on renal NO production, the results are conflicting. Some studies showed that ANG II can stimulate NO release, whereas others reported a decrease in renal NO after ANG II infusion $(3,59)$. Recently, it was shown that in response to ANG II, endothelial NADPH oxidase-derived superoxide anion causes a deficiency of tetrahydrobiopterine, a cofactor of eNOS, leading to a switch from NO to superoxide production by eNOS (15). Taken together, this evidence indicates that the interrelationship between ANG II and NO is very complex. However, the general consensus is that endothelial ANG II signaling negatively regulates NO bioavailability (48). The effects of enalapril treatment on NO metabolism observed in the present study, that is, increases in renal $\mathrm{NO}_{x}$, eNOS protein, and mtNOS activity, favor the concept that, a decrease in ANG II formation favors NO bioavailability.

At the mitochondrial level, in the Enal group, electron transfer through complexes I to III (NADH/cytochrome $c$ oxidoreductase activity) was lower than in the control group, and this effect was prevented by the coadministration of 
L-NAME. The observed response of electron transfer to enalapril treatment is in agreement with a study showing that incubation of isolated kidney cortex mitochondria with enalapril maleate leads to the inhibition of both, respiratory rate (state 3), and respiratory control (46), thus supporting a direct effect of enalapril on $\mathrm{NADH} /$ cytochrome $c$ oxidoreductase. Also, it is worth mentioning that NADH/cytochrome $c$ oxidoreductase activity can be inhibited by high concentrations of NO $(12,57)$.

At physiological concentrations, NO competes with oxygen for the active site of cytochrome oxidase. The binding of NO to cytochrome oxidase may lead to the: 1 ) modulation of tissue oxygen gradients, 2) regulation of mitochondrial respiration (5) and superoxide production (55), and 3) inhibition of apoptosis by preventing cytochrome $c$ release (10). In the Enal group, the observed decrease in cytochrome oxidase activity may also be ascribed to the relatively higher levels of kidney $\mathrm{NO}$ found in this group. However, in the Enal+L-NAME group, mtNOS was completely inhibited by L-NAME, suggesting a role for mitochondrial NO production in the decline of cytochrome oxidase activity observed in the Enal group.

It is interesting to note that the existence of a mtNOS has been reported in different tissues. In rat liver, mtNOS was identified as a myristoylated $\alpha$-isoform of nNOS localized to the inner mitochondrial membrane (22). However, in human endothelial cells, it appears to be the eNOS isoform docked to the outer mitochondrial membrane (28). Recently, evidence was presented in support of the existence of an inducible mtNOS that is likely coded by the same gene as iNOS, in the diaphragm of septic mice (43). Thus, because no unique nuclear gene has been identified for mtNOS, it is assumed be a variant of one of the other NOS isoforms (11).

In accordance with previous results in long-term enalapriltreated rats (17), in this study, we observed that enalapril treatment led to a decrease in Mn-SOD activity. This decrease may be explained by 1) enalapril contributing to the lowering of RAS-dependent superoxide generation and the ensuing prevention of superoxide-induced Mn-SOD synthesis; or 2) the enalapril-dependent increase in NO production, leading to the inactivation of the enzyme. In this setting, it was observed that nitration of a critical residue in the active site of the enzyme leads to Mn-SOD inactivation (50).

In this study, the higher level of UCP-2 protein observed in the Enal group relative to the other groups studied, was associated both with higher $\mathrm{NO}$ and lower $\mathrm{H}_{2} \mathrm{O}_{2}$ productions but was unrelated to changes in MMP These results are in line with previously published evidence indicating that NO (12) and $\mathrm{H}_{2} \mathrm{O}_{2}$ (49) are involved in UCP-2 regulation and that increased UCP-2 levels result in a lower production of cell oxidants $(14,49)$. Also, in brain mitochondria subjected to malate/glutamate sustained respiration, oxidant production by complex I was shown to be independent of mitochondrial membrane potential (69), and in rat myoblasts, UCP-3 overexpression decreased mitochondrial oxidant production but did not affect mitochondrial membrane potential (45).

In summary, enalapril treatment modified several parameters of kidney mitochondrial function, that is, respiratory chain activity (electron transfer from complex I to complex III, and complex IV activity), Mn-SOD activity, and UCP-2 content. These effects may provide a mechanism mediating the positive health effects of RAS-inhibition, involving mitochondria as a key organelle in such actions. The question still remains as to whether enalapril can reach the mitochondria and exert direct effects on mitochondrial components, or whether enalapril acts only at the plasma membrane level, for example, inhibiting ACE activity, leading to an increase in the cellular levels of NO, or other signaling molecules, which would be the species that eventually reach the mitochondria, and improve mitochondrial function. More research in this direction is necessary to assess the physiological relationships between RAS modulation and mitochondrial function.

The results shown in this paper indicate that in healthy rats, inhibition of the RAS with enalapril modifies mitochondrial function and that several of these changes are associated with changes in NO metabolism. These findings provide new insights regarding the relationship between the RAS and mitochondrial metabolism and can help unravel the mechanisms involved in the renal protective effects afforded by RAS inhibition.

\section{GRANTS}

This work was supported by PICT 01-08951 (Agencia Nacional de Promoción Cientifica y Technológica, Argentina). C. G. Fraga is Principal Investigator from Consejo Nacional de Investigaciones Cientificas y Tecnicas, Argentina.

\section{REFERENCES}

1. Aiello S, Noris M, Todeschini M, Zappella S, Foglieni C, Benigni A, Corna D, Zoja C, Cavallotti D, Remuzzi G. Renal and systemic nitric oxide synthesis in rats with renal mass reduction. Kidney Int 52: 171-181, 1997.

2. Arnaiz SL, Coronel MF, Boveris A. Nitric oxide, superoxide, and hydrogen peroxide production in brain mitochondria after haloperidol treatment. Nitric Oxide 3: 235-243, 1999.

3. Badzynska B, Grzelec-Mojzesowicz M, Sadowski J. Effect of exogenous angiotensin II on renal tissue nitric oxide and intrarenal circulation in anaesthetized rats. Acta Physiol Scand 182: 313-318, 2004.

4. Baker HJ, Lindsey JR, Weisbroth SH. The Laboratory Rat, Volume I: Biology and Diseases. New York: Academic, 1979.

5. Beltran B, Mathur A, Duchen MR, Erusalimsky JD, Moncada S. The effect of nitric oxide on cell respiration: a key to understanding its role in cell survival or death. Proc Natl Acad Sci USA 97: 14602-14607, 2000.

6. Boer R, Ulrich WR, Klein T, Mirau B, Haas S, Baur I. The inhibitory potency and selectivity of arginine substrate site nitric-oxide synthase inhibitors is solely determined by their affinity toward the different isoenzymes. Mol Pharmacol 58: 1026-1034, 2000.

7. Boveris A, Costa L, Cadenas E. The mitochondrial production of oxygen radicals and cellular aging. In: Understanding the Process of Aging, edited by Cadenas E and Packer L. New York: Dekker, 1999, p. 1-16.

8. Boveris A, Poderoso JJ. Regulation of oxygen metabolism by nitric oxide. In: Nitric Oxide: Biology and Pathobiology, edited by Ignarro LJ. Los Angeles: Academic, 2000, p. 355-367.

9. Brenner BM, Cooper ME, de Zeeuw D, Keane WF, Mitch WE, Parving HH, Remuzzi G, Snapinn SM, Zhang Z, Shahinfar S. Effects of losartan on renal and cardiovascular outcomes in patients with type 2 diabetes and nephropathy. N Engl J Med 345: 861-869, 2001.

10. Brookes P, Darley-Usmar VM. Hypothesis: the mitochondrial NO(*) signaling pathway, and the transduction of nitrosative to oxidative cell signals: an alternative function for cytochrome C oxidase. Free Radic Biol Med 32: 370-374, 2002.

11. Brookes PS. Mitochondrial nitric oxide synthase. Mitochondrion 3: 187204, 2004.

12. Brookes PS, Levonen AL, Shiva S, Sarti P, Darley-Usmar VM. Mitochondria: regulators of signal transduction by reactive oxygen and nitrogen species. Free Radic Biol Med 33: 755-764, 2002.

13. Capaldi RA, Marusich MF, Taanman JW. Mammalian cytochrome-c oxidase: characterization of enzyme and immunological detection of subunits in tissue extracts and whole cells. Methods Enzymol 260: 117$132,1995$. 
14. Casteilla L, Rigoulet M, Penicaud L. Mitochondrial ROS metabolism: modulation by uncoupling proteins. IUBMB Life 52: 181-188, 2001.

15. Chalupsky K, Cai H. Endothelial dihydrofolate reductase: critical for nitric oxide bioavailability and role in angiotensin II uncoupling of endothelial nitric oxide synthase. Proc Natl Acad Sci USA 102: 90569061, 2005.

16. Chen JW, Hsu NW, Wu TC, Lin SJ, Chang MS. Long-term angiotensin-converting enzyme inhibition reduces plasma asymmetric dimethylarginine and improves endothelial nitric oxide bioavailability and coronary microvascular function in patients with syndrome X. Am J Cardiol 90: 974-982, 2002.

17. de Cavanagh EM, Piotrkowski B, Basso N, Stella I, Inserra F, Ferder L, Fraga CG. Enalapril and losartan attenuate mitochondrial dysfunction in aged rats. FASEB J 17: 1096-1098, 2003.

18. de Cavanagh EM, Toblli JE, Ferder L, Piotrkowski B, Stella I, Fraga CG, Inserra F. Angiotensin II blockade improves mitochondrial function in spontaneously hypertensive rats. Cell Mol Biol (Noisy-le-grand) 51: 573-578, 2005.

19. de Cavanagh EM, Toblli JE, Ferder L, Piotrkowski B, Stella I, Inserra F. Renal mitochondrial dysfunction in spontaneously hypertensive rats is attenuated by losartan but not by amlodipine. Am J Physiol Regul Integr Comp Physiol 290: R1616-R1625, 2006.

20. De Gennaro Colonna V, Rigamonti A, Fioretti S, Bonomo S, Manfredi B, Ferrario P, Bianchi M, Berti F, Muller EE, Rossoni G. Angiotensinconverting enzyme inhibition and angiotensin AT1-receptor antagonism equally improve endothelial vasodilator function in L-NAME-induced hypertensive rats. Eur J Pharmacol 516: 253-259, 2005.

21. Duchen MR. Roles of mitochondria in health and disease. Diabetes 53 Suppl 1: S96-S102, 2004.

22. Elfering SL, Sarkela TM, Giulivi C. Biochemistry of mitochondrial nitric-oxide synthase. J Biol Chem 277: 38079-38086, 2002.

23. Fernandez-Alfonso MS, Gonzalez C. Nitric oxide and the renin-angiotensin system. Is there a physiological interplay between the systems? J Hypertens 17: 1355-1361, 1999.

24. Flohe L, Otting F. Superoxide dismutase assays. Methods Enzymol 105: 93-104, 1984.

25. Forstermann U, Gath I. Purification of isoforms of nitric oxide synthase. Methods Enzymol 268: 334-339, 1996.

26. Fossum E, Moan A, Kjeldsen SE, Devereux RB, Julius S, Snapinn SM, Edelman JM, de Faire U, Fyhrquist F, Ibsen H, Kristianson K, Lederballe-Pedersen $O$, Lindholm LH, Nieminen MS, Omvik P, Oparil S, Wedel H, Dahlof B. The effect of losartan versus atenolol on cardiovascular morbidity and mortality in patients with hypertension taking aspirin: the Losartan Intervention for Endpoint Reduction in hypertension (LIFE) study. J Am Coll Cardiol 46: 770-775, 2005.

27. Fujihara CK, Mattar AL, Vieira JM Jr, Malheiros DM, Noronha Ide L, Goncalves AR, De Nucci G, Zatz R. Evidence for the existence of two distinct functions for the inducible NO synthase in the rat kidney: effect of aminoguanidine in rats with 5/6 ablation. J Am Soc Nephrol 13: 2278 2287, 2002.

28. Gao HM, Liu B, Zhang W, Hong JS. Critical role of microglial NADPH oxidase-derived free radicals in the in vitro MPTP model of Parkinson's disease. FASEB J 17: 1954-1956, 2003.

29. Garrison JC, Peach MJ. Renina y Angiotensina. In: Las Bases Farmacológicas de la Terapéutica (8th ed.), edited by Gilman AG, Rall TW, Nies AS, and Taylor P. Buenos Aires: Ed. Panamericana, 1991, p. 733-746.

30. Ghafourifar P, Cadenas E. Mitochondrial nitric oxide synthase. Trends Pharmacol Sci 26: 190-195, 2005.

31. Goto K, Fujii K, Onaka U, Abe I, Fujishima M. Angiotensin-converting enzyme inhibitor prevents age-related endothelial dysfunction. Hypertension 36: 581-587, 2000.

32. Hatefi Y, Rieske JS. The preparation and properties of DNPH-cytochrome $c$ reductase (Complex I-III of the respiratory chain). Methods Enzymol 10: 225-231, 1967.

33. Hekimi S, Guarente L. Genetics and the specificity of the aging process. Science 299: 1351-1354, 2003.

34. Henriksen EJ, Jacob S. Modulation of metabolic control by angiotensin converting enzyme (ACE) inhibition. J Cell Physiol 196: 171-179, 2003.

35. HOPE Study and Investigators. Effect of Ramipril on cardiovascular and microvascular outcomes in people with diabetes mellitus: results of the HOPE study and MICRO-HOPE substudy. Lancet 355: 253-259, 2000 .
36. Jones BH, Standridge MK, Moustaid N. Angiotensin II increases lipogenesis in 3T3-L1 and human adipose cells. Endocrinology 138: 1512-1519, 1997.

37. Jones OT, Hancock JT. Assays of plasma membrane NADPH oxidase. Methods Enzymol 233: 222-229, 1994.

38. Kimura S, Zhang GX, Nishiyama A, Shokoji T, Yao L, Fan YY, Rahman M, Abe Y. Mitochondria-derived reactive oxygen species and vascular MAP kinases: comparison of angiotensin II and diazoxide. Hypertension 45: 438-444, 2005.

39. Knowles RG, Salter M. Measurement of NOS activity by conversion of radiolabeled arginine to citrulline using ion-exchange separation. Methods Mol Biol 100: 67-73, 1998

40. Landmesser U, Drexler H. Effect of angiotensin II type 1 receptor antagonism on endothelial function: role of bradykinin and nitric oxide. J Hypertens Suppl 24: S39-S43, 2006.

41. Lee MA, Bohm M, Paul M, Ganten D. Tissue renin-angiotensin systems. Their role in cardiovascular disease. Circulation 87, Suppl 5: IV7-IV13, 1993.

42. Lewis EJ, Hunsicker LG, Clarke WR, Berl T, Pohl MA, Lewis JB, Ritz E, Atkins RC, Rohde R, Raz I. Renoprotective effect of the angiotensin-receptor antagonist irbesartan in patients with nephropathy due to type 2 diabetes. $N$ Engl J Med 345: 851-860, 2001.

43. Lopez LC, Escames G, Tapias V, Utrilla P, Leon J, Acuna-Castroviejo D. Identification of an inducible nitric oxide synthase in diaphragm mitochondria from septic mice: its relation with mitochondrial dysfunction and prevention by melatonin. Int J Biochem Cell Biol 38: 267-278, 2006.

44. Lowry OH, Rosebrough NJ, Farr AL, Randall RJ. Protein measurement with the Folin phenol reagent. J Biol Chem 193: 265-275, 1951.

45. MacLellan JD, Gerrits MF, Gowing A, Smith PJ, Wheeler MB, Harper ME. Physiological increases in uncoupling protein 3 augment fatty acid oxidation and decrease reactive oxygen species production without uncoupling respiration in muscle cells. Diabetes 54: 2343-2350, 2005.

46. Merlin ME, Campello AP, Kluppel ML. Enalapril maleate affects 2-oxoglutarate metabolism in mitochondria from the rat kidney cortex. Cell Biochem Funct 12: 21-28, 1994.

47. Mollnau H, Wendt M, Szocs K, Lassegue B, Schulz E, Oelze M, Li H, Bodenschatz M, August M, Kleschyov AL, Tsilimingas N, Walter U, Forstermann U, Meinertz T, Griendling K, Munzel T. Effects of angiotensin II infusion on the expression and function of $\mathrm{NAD}(\mathrm{P}) \mathrm{H}$ oxidase and components of nitric oxide/cGMP signaling. Circ Res 90: E58-E65, 2002.

48. Nakashima H, Suzuki H, Ohtsu H, Chao JY, Utsunomiya H, Frank GD, Eguchi S. Angiotensin II regulates vascular and endothelial dysfunction: recent topics of angiotensin II type-1 receptor signaling in the vasculature. Curr Vasc Pharmacol 4: 67-78, 2006.

49. Negre-Salvayre A, Hirtz C, Carrera G, Cazenave R, Troly M, Salvayre $\mathbf{R}$, Penicaud $\mathbf{L}$, Casteilla $\mathbf{L}$. A role for uncoupling protein-2 as a regulator of mitochondrial hydrogen peroxide generation. FASEB $J$ 11: 809-815, 1997.

50. Nilakantan V, Halligan NL, Nguyen TK, Hilton G, Khanna AK, Roza AM, Johnson CP, Adams MB, Griffith OW, Pieper GM. Post-translational modification of manganese superoxide dismutase in acutely rejecting cardiac transplants: role of inducible nitric oxide synthase. $J$ Heart Lung Transplant 24: 1591-1599, 2005.

51. Nisoli E, Clementi E, Paolucci C, Cozzi V, Tonello C, Sciorati C, Bracale R, Valerio A, Francolini M, Moncada S, Carruba MO. Mitochondrial biogenesis in mammals: the role of endogenous nitric oxide. Science 299: 896-899, 2003.

52. Opie LH. Renoprotection by angiotensin-receptor blockers and ACE inhibitors in hypertension. Lancet 358: 1829-1831, 2001.

53. Pecqueur C, Alves-Guerra MC, Gelly C, Levi-Meyrueis C, Couplan E, Collins S, Ricquier D, Bouillaud F, Miroux B. Uncoupling protein 2, in vivo distribution, induction upon oxidative stress, and evidence for translational regulation. J Biol Chem 276: 8705-8712, 2001.

54. Rossi MA, Ramos SG, Prado CM. Chronic inhibition of nitric oxide synthase induces hypertension and cardiomyocyte mitochondrial and myocardial collagen remodelling in the absence of hypertrophy. J Hypertens 21: 993-1001, 2003.

55. Sarkela TM, Berthiaume J, Elfering S, Gybina AA, Giulivi C. The modulation of oxygen radical production by nitric oxide in mitochondria. J Biol Chem 276: 6945-6949, 2001. 
56. Scaduto RC Jr, Grotyohann LW. Measurement of mitochondrial membrane potential using fluorescent rhodamine derivatives. Biophys $J$ 76: 469-477, 1999.

57. Schild L, Jaroscakova I, Lendeckel U, Wolf G, Keilhoff G. Neuronal nitric oxide synthase controls enzyme activity pattern of mitochondria and lipid metabolism. FASEB J 20: 145-147, 2006.

58. Schon EA, Manfredi G. Neuronal degeneration and mitochondrial dysfunction. J Clin Invest 111: 303-312, 2003.

59. Siragy HM, Carey RM. The subtype 2 (AT2) angiotensin receptor mediates renal production of nitric oxide in conscious rats. J Clin Invest 100: 264-269, 1997.

60. Strazzullo P, Galletti F. Impact of the renin-angiotensin system on lipid and carbohydrate metabolism. Curr Opin Nephrol Hypertens 13: 325-332, 2004.

61. Szabo A, Lutz J, Schleimer K, Antus B, Hamar P, Philipp T, Heemann U. Effect of angiotensin-converting enzyme inhibition on growth factor mRNA in chronic renal allograft rejection in the rat. Kidney Int 57: 982-991, 2000.

62. Takemoto M, Egashira K, Usui M, Numaguchi K, Tomita H, Tsutsui H, Shimokawa H, Sueishi K, Takeshita A. Important role of tissue angiotensin-converting enzyme activity in the pathogenesis of coronary vascular and myocardial structural changes induced by long-term blockade of nitric oxide synthesis in rats. J Clin Invest 99: 278-287, 1997.

63. Touyz RM. Reactive oxygen species and angiotensin II signaling in vascular cells-implications in cardiovascular disease. Braz J Med Biol Res 37: 1263-1273, 2004.

64. Touyz RM. Reactive oxygen species, vascular oxidative stress, and redox signaling in hypertension: what is the clinical significance? Hypertension 44: 248-252, 2004.

65. Valdez LB, Zaobornyj T, Boveris A. Functional activity of mitochondrial nitric oxide synthase. Methods Enzymol 396: 444-455, 2005.
66. Vaziri ND, Ni Z, Wang XQ, Oveisi F, Zhou XJ. Downregulation of nitric oxide synthase in chronic renal insufficiency: role of excess PTH. Am J Physiol Renal Physiol 274: F642-F649, 1998.

67. Verdon CP, Burton BA, Prior RL. Sample pretreatment with nitrate reductase and glucose-6-phosphate dehydrogenase quantitatively reduces nitrate while avoiding interference by NADP+ when the Griess reaction is used to assay for nitrite. Anal Biochem 224: 502-508, 1995.

68. Vodovotz Y, Geiser AG, Chesler L, Letterio JJ, Campbell A, Lucia MS, Sporn MB, Roberts AB. Spontaneously increased production of nitric oxide and aberrant expression of the inducible nitric oxide synthase in vivo in the transforming growth factor beta 1 null mouse. $J$ Exp Med 183: 2337-2342, 1996.

69. Votyakova TV, Reynolds IJ. DeltaPsi(m)-dependent and -independent production of reactive oxygen species by rat brain mitochondria. $J \mathrm{Neu}$ rochem 79: 266-277, 2001.

70. Wallace DC. Mitochondrial diseases in man and mouse. Science 283: 1482-1488, 1999.

71. Weihe W. The laboratory rat. In: UFAW Handbook on the Care and Management of Laboratory Animals (6th ed.), edited by Popñ T. Harlow, Essex, UK: Longman Scientific and Technical, 1987.

72. Wilcox CS. Reactive oxygen species: roles in blood pressure and kidney function. Curr Hypertens Rep 4: 160-166, 2002.

73. Wisloff U, Najjar SM, Ellingsen O, Haram PM, Swoap S, Al-Share Q, Fernstrom M, Rezaei K, Lee SJ, Koch LG, Britton SL. Cardiovascular risk factors emerge after artificial selection for low aerobic capacity. Science 307: 418-420, 2005.

74. Zhang X, Xie YW, Nasjletti A, Xu X, Wolin MS, Hintze TH. ACE inhibitors promote nitric oxide accumulation to modulate myocardial oxygen consumption. Circulation 95: 176-182, 1997.

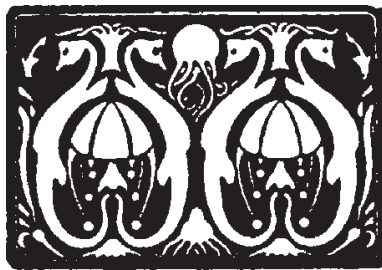

